Skill-Biased Technological Change:

Is there Hope for the Unskilled?

Matthias Weiss

45-2004

March 2004 


\title{
Skill-Biased Technological Change: \\ Is there Hope for the Unskilled?
}

\author{
Matthias Weiss* \\ mea \\ Universität Mannheim \\ L13, 17 \\ 68131 Mannheim \\ Germany \\ weiss@mea.uni-mannheim.de
}

\begin{abstract}
This paper challenges the common view that skill-biased technological change boosts wage inequality. In a multi-sector economy, relative wages depend not only on relative productivities but also on relative goods prices. If ther are complementarities between goods that do not benefit greatly from technological innovations and other goods whose production costs fall in the course of technical progress, the relative price of these "low-tech" goods rises. If the production of these "low-tech" goods is intensive in the use of unskilled labor, unskilled workers benefit from this increase in the relative goods price.

This paper presents a simple two-sector, two-factor model of perpetual exogenous skill-biased technological change. The model is able to explain the increase in wage inequality in the 1980s and the subsequent stabilization of the wage structure in the 1990s.
\end{abstract}

Keywords: Skill-Biased Technological Change, Wage Inequality, Factor Substitution JEL Classification: E24, J31, O30

${ }^{*}$ I am indebted to Martin Hellwig for ongoing discussion and advice. I would also like to thank Philippe Aghion, Bernd Fitzenberger, Simone Kohnz, Melanie Lührmann, John van Reenen, and Joachim Winter for valuable comments and suggestions. The usual disclaimer applies. 


\section{Introduction}

The aim of this paper is to show that perpetual skill-biased technological change (SBTC) does not necessarily lead to ever-increasing wage inequality, even if wages and prices are perfectly flexible and labor supply cannot react to changes in labor demand. Under plausible assumptions, skill-biased technological change is shown to lead to a rise and subsequent fall in the skill premium, a pattern that is consistent with the actual evolution of wages in the 1980s and 1990s.

The recent consensus seems to be that technological change has been "skill-biased" for the past several decades in that productivities of more skilled workers have increased more rapidly than those of less skilled workers. The rapid spread of computers in workplaces has been cited as the example of changes in technology that boost productivities of skilled workers while leaving the productivities of the unskilled virtually unaffected. This "skillbias" in technological change has received so much attention because - allegedly - it leads to increasing wage inequality. If workers are paid according to their productivities, the argument goes, changes in relative productivities must imply changes in relative wages. ${ }^{1}$ A natural question arising from these considerations is: What will happen, if technological change continues to be skill-biased? Gregg and Manning (1997) are quite pessimistic about the long-run prospects for unskilled workers:

"As there is no reason to think that these trends will not continue into the future, it must be anticipated that the labour market position of the unskilled will continue to deteriorate." (Page 1176)

Similarly, Nahuis and de Groot (2003) argue that ...

"... an obvious conclusion is that the demand for skill will continue to grow and that the supply of skill can no longer accommodate this in the near future due to the simple fact that talent is limited by nature and that the cost of increasing the supply of skills further increases exponentially." (Page 8)

In this paper, I show, that these views are overly pessimistic. Even if technological change continues to be skill-biased for ever, if wages and prices are perfectly flexible, and if the

\footnotetext{
${ }^{1}$ If the elasticity of substitution between unskilled and skilled labor is larger than 1, skill-biased laboraugmenting technological change implies that the wage for skilled labor increases faster than the wage for unskilled labor. Attempts have been undertaken to estimate the elasticity of substitution between unskilled and skilled labor. The majority of these estimates are between 1 and 2. See eg Autor, Katz, and Krueger (1998) who argue that a consensus estimate is a value around 1.5. These findings have led to the conclusion that skill-biased technological change necessarily boosts wage inequality. Levy and Murnane (1992) and more recently Gottschalk and Smeeding (1997) survey the empirical literature on this subject. For a survey of theories of growing earnings inequality, see Section 3 in Aghion, Caroli, and García-Peñalosa (1999). For a discussion of the "European Case" where supposedly skill-biased technological change leads to increasing unemployment rather than increasing wage inequality, see the conclusion.
} 
supply of skills is fixed, wage inequality will most likely not increase without bounds. Production factors are paid according to their marginal value which is marginal productivity times the output price. If more than one good is produced and workers with different skills have different comparative advantages in production, the effects of technological change on output prices become relevant. And if final goods are not easily substitutable, technological change has considerable effects on relative goods prices so that workers who do not benefit directly from technical progress via productivity gains can benefit indirectly via induced changes in goods prices.

The more recent literature on wage inequality and skill-premia concludes that the wage structure has indeed stabilized or even narrowed during the 1990s despite continuing or even accelerating advances in computer technology in the course of the IT-led new economy boom:

"A key problem for the SBTC hypothesis is that wage inequality stabilized in the 1990s despite continuing advances in computer technology."

Card and DiNardo (2002), page $733 .^{2}$

"Our results for the 1990's suggest that ... the rapid growth in the relative wages for college graduates has slowed significantly or in some cases may have even stopped since about 1994."

Murphy and Welch (2001), page 343.

"Technological change in the 1990s, especially the late 1990s has not adversely affected low-wage workers. This calls into question whether the adverse wage trends for low-wage workers in the 1980s was due to non-technical factors."

Mishel and Bernstein (2001), page 4.

More evidence on the narrowing of the wage structure in the 1990s is given in Bernstein and Mishel (1999) or Katz (2000). Machin (2002) and Prasad (2002) obtain corresponding results for the evolution of the wage structure in the UK in the 1990s. ${ }^{3}$ Some of these papers call into question the role of technological change for the evolution of the wage structure in the 1980s and 1990s (Card and DiNardo (2002) and Mishel and Bernstein (2001)). Others (Murphy and Welch (2001)) hypothesize that increased supply of skilled workers in the 1990s has compensated the skill-bias in labor demand:

"The story we prefer is one of relatively stable growth in the demand for

\footnotetext{
${ }^{2}$ Daly and Valletta (2003) find very similar results using data from the Panel Study of Income Dynamics (PSID) while Card and DiNardo calculate their measures of wage inequality from the Current Population Survey (CPS).

${ }^{3}$ Dickens and Ellwood (2001) and Nickell (2004) study income inequality and poverty in general. They also find a sharp rise until 1992 and stabilization thereafter.

The evolution of the wage structure in Continental Europe has been somewhat different but also harder to interpret because a variety of constitutional frictions keep wages from adjusting to changes in supply and demand.
} 
educated workers over the past three decades with fluctuating supply growth generating the observed pattern of changes in wage premiums." (Page 345)

This latter view is hard to reconcile with the empirical evidence. Autor, Katz, and Krueger (1998), eg, report changes in the relative supply of skilled workers over the past several decades. The number of college graduates relative to the number of high school graduates and dropouts has risen sharply in the 1970s and only moderately in the 1980s which is consistent with Murphy and Welch's story. But during the 1990s, the growth rate of the relative supply of college vs. non-college graduates has fallen further (see Table 1) while the skill-premium - depending on how it is measured - has been rising more slowly or even been falling. This implies that the skill-bias in technological change has either faded or - for some reason - has not translated into a skill-bias in labor demand.

Table 1: Changes in the Skill Composition of U.S. Employment, 1940 - 1996

\begin{tabular}{cc}
\hline & $\begin{array}{c}\text { Change in college/noncollege } \\
\text { log relative employment }\end{array}$ \\
\hline $1940-1950$ & 2.14 \\
$1950-1960$ & 3.43 \\
$1960-1970$ & 3.00 \\
$1970-1980$ & 4.69 \\
$1980-1990$ & 2.88 \\
$1990-1996$ & 1.51 \\
\hline Source: Autor, Katz, and Krueger (1998), Table 1.
\end{tabular}

Source: Autor, Katz, and Krueger (1998), Table 1.

This paper presents a model in which technological change continues to be skill-biased, but this skill-bias in technology does not translate into a perpetual skill-bias in labor demand. The theoretical results of this paper are consistent with the actual evolution of the skillspecific wage structure of the 1980s and the 1990s. Initially, skill-biased technological change has a skill-biased effect on labor demand (resulting in rising skill-premia), but as technological change continues to be skill-biased, the skill-bias in labor demand dies down (and the wage structure stabilizes).

The reason for this seemingly unintuitive result is that labor demand depends not only on labor productivity but also on the output price of the good that is being produced. In multi-sector economies, relative wages are therefore determined not only by relative productivities but also by relative goods prices. In this setting, the degree of substitutability in consumption demand is as important for the effects of technological change on relative factor prices as the degree of substitutability in factor demand.

The effects of skill-biased technological change have mostly been studied within the 
framework of one-sector models where the level of the output price is irrelevant. ${ }^{4}$ This simplification is "innocent" if one of the following two requirements is met:

1. Technological change has the same effect on all sectors (so that relative goods prices are not affected by technological change) or

2. all sectors produce with the same relative factor intensities (in which case relative goods prices have no effect on the relative factor price).

I argue in this paper, that in reality neither requirement is met. Technological change affects different sectors differently (think of services vs. ICT) and factor intensities differ across sectors. If there are complementarities between the goods from these different sectors, the relative price of the "low-tech" goods rises in the course of technical progress. If the sectors that benefit relatively more from technical progress are skill-intensive, the rise in the relative goods price may offset the decline in relative productivities so that the relative wage - which is the product of both - may rise. I show in this paper that if the elasticity of substitution between "high-tech-skill-intensive" and "low-tech-unskillintensive" goods is at most equal to 1 , the rise of the relative price of the low-tech good rises offsets the fall of the relative productivity of unskilled labor falls in the long run and the wage structure stabilizes.

Leamer (1996), Leamer (1997), Slaughter and Haskel (1999), Haskel (2000), and Haskel and Slaughter (2002) study the effects of technological change on the wage structure in multi-sector economies. Leamer considers a two-sector economy in an environment with technological change and foreign trade. Leamer's analysis differs from mine in several respects: He considers a small open economy where goods prices are exogenous while in this paper, the endogenous reaction of goods prices to technological change is crucial for the effects on factor prices. Furthermore, he restricts the analysis to a Leontief technology where factors are perfect complements. In contrast, I consider substitutability between production factors in accordance with the empirical evidence. ${ }^{5}$ The focus of Leamer's paper differs from this paper in that he is "in search for Stolper-Samuelson effects on wages". He studies the effects of trade (and technology) on factor prices which is why he needs goods prices to be exogenous. Slaughter and Haskel (1999) and Haskel (2000) study the relative importance of sector-bias and factor-bias of technological change in affecting the skill-specific wage structure. They derive conditions under which the factorbias is irrelevant and the evolution of skill premia is determined by the sector-bias of technological change. These conditions are essentially

- a high degree of substitutability between the two final goods (machinery and apparel),

- a high degree of complementarity between unskilled and skilled labor, or

- the existence of a non-traded sector.

\footnotetext{
${ }^{4}$ See for example Acemoglu (2002).

${ }^{5} \mathrm{See}, \mathrm{eg}$, Autor, Katz, and Krueger (1998).
} 
They show that under either of these assumptions, technological change that is biased in favor of the skill-intensive sector leads to rising wage inequality irrespective of a factor bias. Haskel and Slaughter (2002) conclude that the evolution of skill premia in the 1970s and 1980s can be explained by technological change that was generally concentrated in unskill-intensive sectors in the 1970s and in skill-intensive sectors in the 1980s. Their study does not cover the 1990s when skill premia stabilized despite continuing technical progress in the skill-intensive sectors during the IT-led new economy boom.

Quite contrary, I argue in this paper that technological change that is concentrated in the skill-intensive sector and favors skilled labor will under plausible assumptions lead to a rise and a subsequent fall in skill premia. These "plausible assumptions" are

- complementarity between the final goods (elasticity of substitution in consumption demand smaller than or equal to 1$)^{6}$ and

- substitutability between unskilled and skilled labor (elasticity of substitution in factor demand larger than 1$)^{7}$.

In a recent paper, Kongsamut, Rebelo, and Xie (2001) also consider the dynamics of sectoral factor reallocation in a multiple-sector growth model but with capital and labor as the two factors of production. While in my paper the driving force for factor reallocation is the differential in productivity growth, in their paper, sectoral factor reallocation is triggered by growing income and different income elasticities in the demands for different goods. As consumers become richer, their demand for agricultural goods grows less than proportionately while the demand for services grows more than proportionately. ${ }^{8}$ Both these effects are probably at work in the "real world" and both lead to employment growth in services relative to manufacturing and agriculture.

In this paper, I focus on the long run prospects of unskilled workers in the presence of skill-biased technological change. I show that in multi-sector economies where technical change affects different sectors differently, skill-biased technological change does not necessarily lead to ever increasing wage inequality. If there are complementarities between the products from these different sectors, the relative price of the "low-tech" goods rises in the course of technical progress. If the "low-tech" sectors are unskill-intensive, the rise in the relative goods price may offset the decline in relative productivities so that the relative wage of unskilled workers - which is the product of both - may rise.

The remainder of the paper is organized as follows: In Section 2, I give a short illus-

\footnotetext{
${ }^{6}$ The idea is that a higher level of aggregation implies a lower level of substitutability. Different sorts of apples (Golden Delicious vs. Granny Smith) are fairly close substitutes. Apples in general vs. oranges are still quite close substitutes but not as close as different sorts of apples. If we increase the level of aggregation (fruit in general vs. vegetables, food in general vs. books, services vs. (other) goods) the degree of substitutability declines. I consider in this paper only 2 goods: services and (all other) goods. Therefore, I assume that the elasticity of substitution in consumption demand is at most equal to 1.

${ }^{7}$ Autor, Katz, and Krueger (1998) argue that a consensus estimate is a value around 1.5.

${ }^{8}$ Kongsamut, Rebelo, and Xie (2001) also restrict services to only those that require no skills and are partly done by everyone in home production.
} 
tration of the argument of this paper using the example of hairdressers (whose wages grow despite the absence of productivity gains). In Section 3, a simple two-sector, two-factor model of exogenous technological change is developed. Within this basic model, the shortand long-run effects of skill-biased technological change are discussed in Section 4. Section 5 discusses the results and concludes.

\section{Hairdressing: An Illustrative Example}

"Hairdressing has been the unnoticed miracle industry of the past decade, growing faster than any other UK sector. According to the Labour Force Survey, the number of hairdressers grew more than 300 per cent between 1992 and 1999. That was more than three times the growth of consultants and half as fast again as that of software engineers. ...

However, the success of hairdressers is at odds with everything we have been led to believe about successful sectors. First is the belief that to do well you must be innovative or have exploited technological change."

(Lucy Kellaway in the Financial Times, Jan 7, 2002)

How can this apparent puzzle be explained? Ms Kellaway reckons that people are just stupid enough to pay a too high price for a bad service. This hints into the direction of irrational behavior. With the model presented in Section 3, this puzzle can be explained within the standard framework of rationally behaving agents in perfectly functioning markets. How can the hairdressing trade thrive without being innovative or exploiting technical progress? Hairdressing can thrive only if it can attract hairdressers by paying them competitive wages. And indeed, as can be seen from Figure 1, the wages for hairdressers in West Germany, eg, have increased even faster than the average wage over all occupations between 1992 and 1999. ${ }^{9}$ But how can the wages of hairdressers grow in the absence of any noteworthy gains in labor productivity? The reason for this increase in the relative wage and the relative size of the hairdressing sector is of course that haircuts are complements rather than substitutes to other goods (which benefit from technical progress). If haircuts could be substituted for easily by computers, the increase in the relative production costs of haircuts would drive them out of the market. But consumers want both, computers and haircuts. And as their incomes rise, they are willing to pay more and more for a haircut. Accordingly, hairdressers cannot be substituted for by computer engineers. Therefore, the lack of productivity gains does not harm their relative position. They benefit from the increase in the relative price for haircuts which translates into a higher wage. ${ }^{10}$

\footnotetext{
${ }^{9}$ Over the past 42 years, the average rates of wage growth have been $5,9 \%$ p.a. for hairdressers and $5,8 \%$ p.a. for all sectors.

${ }^{10}$ The hairdressers' (hourly) wage is equal to the price for a haircut times the hairdresser's productivity (number of haircuts per hour): wage $_{\text {hairdresser }}=$ price $_{\text {haircut }} \cdot$ productivity hairdresser $_{\text {. }} \mathrm{A}$ computer engineer's wage, eg, is equal to the price of a computer times the engineer's productivity:
} 
Hourly Wages: Hairdressing vs. all Sectors

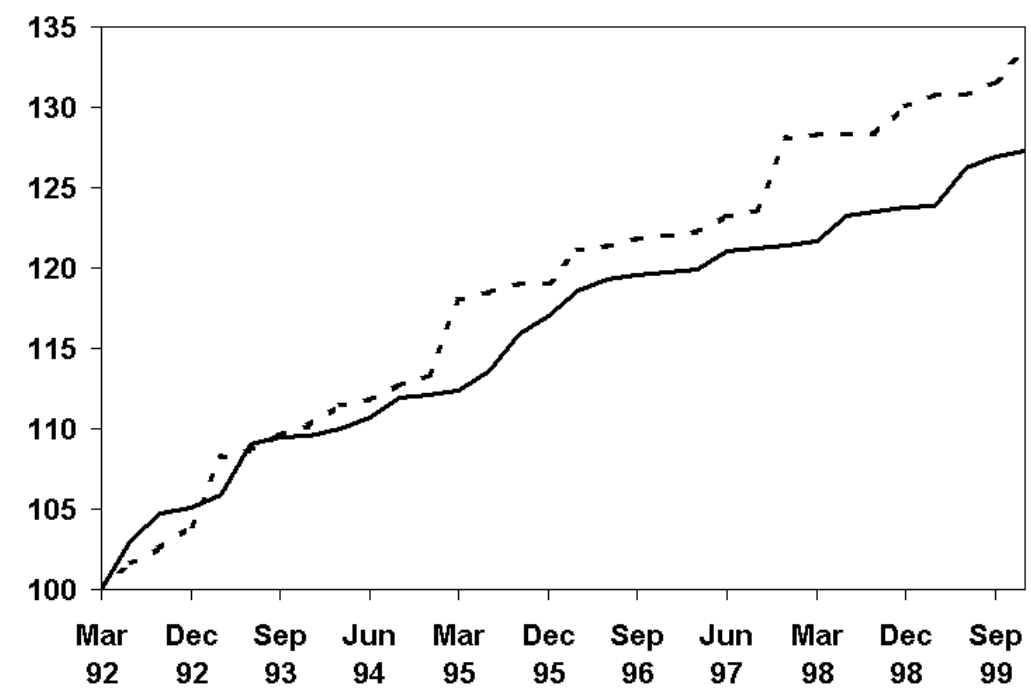

- - hairdressing
- all Sectors

Figure 1: Index of hourly standard wages in West-Germany (1991=100). Source: Statistisches Bundesamt.

In this example, it is rather obvious that the relative wage of hairdressers does not only depend on their relative productivity but also on the relative price of haircuts. The point of this paper is, that - more generally - the relative wage for unskilled labor depends not only on the relative productivity of unskilled workers but also on the relative price of the goods in whose production unskilled workers have their comparative advantage.

\section{The Basic Model}

I study the general equilibrium of an economy with two consumption goods $i=1,2$ (eg, services and manufactured goods) which are produced using two factor inputs $j=1,2$ (eg, unskilled and skilled labor). Both types of input factors are supplied by a continuum of homogeneous consumers. Both consumption goods are produced by a continuum of homogeneous firms. Consumers and firms act as price-takers on input and output markets. Technological change is exogenous and factor-augmenting. The model is essentielly static.

wage $_{\text {engineer }}=$ price $_{\text {computer }} \cdot$ productivityengineer. Accordingly, the relative wage is equal to the relative productivity times the relative goods price.

$$
\frac{\text { wage }_{\text {hairdresser }}}{\text { wage }_{\text {engineer }}}=\frac{\text { price }_{\text {haircut }}}{\text { price }_{\text {computer }}} \cdot \frac{\text { productivity }_{\text {hairdresser }}}{\text { productivity }_{\text {engineer }}}
$$

The relative productivity of hairdressers can be expected to fall further in the future but as long as the relative price of haircuts increases fast enough relative to the price of computers, their relative wage does not fall. The effect of changes in relative productivities on relative goods prices depends on the elasticity of substitution in consumption demand. 
Neither capital investment nor R\&D activities constitute links from one period to the next. The only source of change over time is exogenous technological change.

\subsection{Firms}

In each sector $i=1,2$, firms produce consumption good $i$ using both factor inputs $j=1,2$. The production technology in sector $i$ at time $t$ is given by the following production function: ${ }^{11}$

$$
Y_{i}=\sum_{j=1}^{2}\left(\theta_{i j} \cdot e^{\lambda_{i j} \cdot t} \cdot l_{i j}\right)^{\alpha}, \quad 0<\alpha<1 .
$$

$l_{i j}$ is employment of factor $j$ in industry $i . \quad \lambda_{i j}$ reflects the evolution of productivity of factor $j$ in sector $i$ over time $t$. While $\lambda_{i j}$ accounts for differences in the speed of factor productivity growth, $\theta_{i j}$ accounts for differences in factor productivity that are constant over time. ${ }^{12}$ The elasticity of substitution between the two inputs is $\zeta=\frac{1}{1-\alpha}>1$. I restrict the analysis to substitution elasticities larger than one because (i) this is the case where - allegedly - factor-biased technological change leads to an increase in factor price inequality, (ii) it seems to be the empirically relevant scenario (see, eg, Autor, Katz, and Krueger (1998)), and (iii) it enables me to use a simpler specification of the technology without substantial loss of generality. ${ }^{13}$

Firms maximize profits

$$
\pi_{i}=p_{i} \cdot Y_{i}-\sum_{j=1}^{2} w_{i j} \cdot l_{i j}
$$

taking the price of consumption good $i, p_{i}$, and the price of factor $j$ in sector $i, w_{i j}$, as exogenously given. ${ }^{14}$

\subsection{Consumers}

Each input factor $j=1,2$ is supplied by a continuum of mass one of homogeneous individuals who derive utility from consuming the two final goods $i=1,2$. Each individual of

\footnotetext{
${ }^{11}$ Due to technical progress, technology varies over time. As a consequence, all prices and quantities vary over time. For ease of representation, I omit the time subscripts.

${ }^{12}$ Throughout most of the paper, I assume that $\theta_{i 1}=1<\theta_{i 2}=\theta$, ie, in both sectors, factor 2 is more productive than factor 1. I also discuss the illustrative special case where factor $k$ is used only in sector $k$ so that $\theta_{i j}=\left\{\begin{array}{lll}0 & \Leftrightarrow & i \neq j \\ 1 & \Leftrightarrow & i=j\end{array}\right.$. In this case, factors are perfectly immobile across sectors as in the example of hairdressing.

${ }^{13}$ The more common CES specification would be $Y_{i}=\left(\sum_{j=1}^{2}\left(\theta_{i j} \cdot e^{\lambda_{i j} \cdot t} \cdot l_{i j}\right)^{\alpha}\right)^{\frac{1}{\alpha}}$. Regarding substitutability/complementarity of production factors, the simpler specification I use has the same properties. The additive separability allows a clearer representation of the results.

${ }^{14}$ In equilibrium, the price of factor $j$ will of course be equal across sectors $i$.
} 
skill type $j$ supplies inelastically one unit of input factor $j$. Individual factor supply $L_{i j}$ is offered to the sector with the highest wage for factor $j$ :

$$
L_{i j}=\left\{\begin{array}{cl}
0 & \Leftrightarrow w_{i j}<w_{i^{\prime} j} \\
L_{i j} \in[0,1] & \Leftrightarrow w_{i j}=w_{i^{\prime} j} \\
1 & \Leftrightarrow w_{i j}>w_{i^{\prime} j}
\end{array} \quad \text { and } \quad \sum_{i=1}^{2} L_{i j}=1\right.
$$

All consumers share the same CES utility function:

$$
U_{j}=\left(\sum_{i=1}^{2} C_{i j}^{\rho}\right)^{\frac{1}{\rho}}, \quad j=1,2, \rho<1
$$

where $C_{i j}$ is consumption of final good $i$ by a type $j$ consumer. The elasticity of substitution between the two consumption goods is $\sigma=1 /(1-\rho)$. Since there is no capital in the model economy, the entire production is consumed instantaneously, so that intertemporal substitution is not possible. Firms do not invest and consequently, consumers do not save. Therefore, maximization of lifetime utility is equivalent to period-wise maximization of per-period-utility and discounting is irrelevant. All consumers hold equal shares of all firms. Consumers maximize utility subject to the budget constraint that consumption expenditures must equal factor income $w_{j}$ and profit shares $\pi$

$$
w_{j}+\pi=\sum_{i=1}^{2} p_{i} \cdot c_{i j}, \quad j=1,2
$$

\subsection{General Equilibrium}

Demands and supplies of consumption goods and factors are coordinated through prices on respective markets. Households and firms act as price takers on all markets.

Definition 1 An equilibrium corresponds to a price system $\left(\left\{w_{j}\right\}_{j=1,2},\left\{p_{i}\right\}_{i=1,2}\right)$ and an allocation $\left(\left\{L_{i j}\right\}_{i, j=1,2},\left\{c_{i j}\right\}_{i, j=1,2},\left\{l_{i j}\right\}_{i, j=1,2},\left\{Y_{i}\right\}_{i=1,2}\right)$ that satisfy the following conditions:

- (Utility Maximization): Given the price system $\left(\left\{w_{j}\right\}_{j=1,2},\left\{p_{i}\right\}_{i=1,2}\right)$, the strategy $\left(\left\{L_{i j}\right\}_{i=1,2},\left\{c_{i j}\right\}_{i=1,2}\right)$ maximizes the utility (3) of each household of type $j=$ 1,2 under the budget constraint (4).

- (Profit Maximization): Given the price system $\left(\left\{w_{j}\right\}_{j=1,2},\left\{p_{i}\right\}_{i=1,2}\right)$, the production plan $\left(\left\{l_{i j}\right\}_{j=1,2}, Y_{i}\right)$ maximizes profits (2) of each firm in sector $i=1,2$.

- (Market Clearing):

For each consumption good $i=1,2: \quad Y_{i}=\sum_{j=1}^{2} c_{i j}$.

For each production factor $j=1,2: \quad \sum_{i=1}^{2} L_{i j}=1=\sum_{i=1}^{2} l_{i j}$. 
Proposition 1 An equilibrium exists and is unique. The relative goods price $p=p_{1} / p_{2}$ as a function of technology and preference parameters $\alpha, \theta_{i j}, \lambda_{i j}$, and $\rho$ is given implicitly by

$$
p^{\frac{1}{1-\rho}+\frac{\alpha}{1-\alpha}}=\frac{\sum_{j=1}^{2}\left(\frac{\theta_{2 j} \cdot e^{\lambda_{2 j} \cdot t}}{p^{\frac{1}{1-\alpha}} \cdot\left[\frac{\theta_{1 j}}{\theta_{2 j}} \cdot e^{\left(\lambda_{1 j}-\lambda_{2 j}\right) \cdot t}\right]^{\frac{\alpha}{1-\alpha}}+1}\right)^{\alpha}}{\sum_{j=1}^{2}\left(\frac{\left[\frac{\theta_{1 j}}{\theta_{2 j}^{\alpha}} \cdot e^{\left(\lambda_{1 j}-\alpha \cdot \lambda_{2 j}\right) \cdot t}\right]^{\frac{1}{1-\alpha}}}{p^{\frac{1}{1-\alpha}} \cdot\left[\frac{\theta_{1 j}}{\theta_{2 j}} \cdot e^{\left(\lambda_{1 j}-\lambda_{2 j}\right) \cdot t}\right]^{\frac{\alpha}{1-\alpha}}+1}\right)^{\alpha}}
$$

The relative factor price as a function of the relative goods price $p$ is:

$$
\omega=\frac{w_{1}}{w_{2}}=\left[\frac{\sum_{i=1}^{2}\left(\theta_{i 1}^{\alpha} \cdot e^{\alpha \cdot \lambda_{i 1} \cdot t} \cdot p_{i}\right)^{\frac{1}{1-\alpha}}}{\sum_{i=1}^{2}\left(\theta_{i 2}^{\alpha} \cdot e^{\alpha \cdot \lambda_{i 2} \cdot t} \cdot p_{i}\right)^{\frac{1}{1-\alpha}}}\right]^{1-\alpha}
$$

Proof. See Appendix A.1.

Within the framework of this general two-sector, two-factor model, I will now discuss the effects of skill-biased technological change on the wage structure.

\section{Short- and Long-Run Effects of Skill-Biased Technological Change}

In this section, I consider the short- and long-run effects of skill-biased technological change in an economy with two sectors, manufacturing $(i=m)$ and services $(i=s)$, and two production factors, unskilled $(j=u)$ and skilled labor $(j=s)$. I assume that technical progress is slow in the service sector. ${ }^{15}$ In the manufacturing sector, technical progress is assumed to be fast and skill-biased. ${ }^{16}$

\subsection{Technology}

For simplicity, I assume

$$
\lambda_{s u}=\lambda_{s s}=\lambda_{m u}=0<\lambda_{m s}=\lambda \quad \text { and } \quad \theta_{s u}=\theta_{m u}=1<\theta_{s s}=\theta_{m s}=\theta .
$$

\footnotetext{
${ }^{15}$ One can think of this "service sector" as comprising all sectors of an economy that do not greatly benefit from technical progress such as services like the hotel business, catering trade, child care, hair-dressing, house-cleaning, pizza-delivery, etc.

${ }^{16}$ This "manufacturing sector" stands for the part of the economy where technical progress leads to productivity gains because new machines increase productivity. It is also meant to include those services that benefit, eg, from the introduction of computers like banking, etc.
} 
Technological change affects only manufacturing (sector $m$ ) and whithin manufacturing only the productivity of skilled labor (factor $s$ ). Skilled workers have a productivity advantage $\theta>1$ in both sectors. Furthermore, I normalize the price of the manufactured good to $p_{m}=1$. The production functions simplify to

$$
Y_{s}=l_{s u}^{\alpha}+\left(\theta \cdot l_{s s}\right)^{\alpha}, \quad Y_{m}=l_{m u}^{\alpha}+\left(\theta \cdot e^{\lambda \cdot t} \cdot l_{m s}\right)^{\alpha}
$$

Unskilled labor's productivity is not affected at all by technical progress. Skilled labor benefits from technical progress only when employed in manufacturing. The question of interest in this setting is whether or not technical progress (or its absence) causes the relative wage of unskilled labor to fall to 0 .

\subsection{Analysis}

In this setting, equilibrium employment simplifies to:

$$
l_{s u}=\frac{p^{\frac{1}{1-\alpha}}}{p^{\frac{1}{1-\alpha}}+1} \quad l_{s s}=\frac{p^{\frac{1}{1-\alpha}}}{p^{\frac{1}{1-\alpha}}+e^{\frac{\alpha}{1-\alpha} \cdot \lambda \cdot t}} \quad l_{m u}=\frac{1}{p^{\frac{1}{1-\alpha}}+1} \quad l_{m s}=\frac{e^{\frac{\alpha}{1-\alpha} \cdot \lambda \cdot t}}{p^{\frac{1}{1-\alpha}}+e^{\frac{\alpha}{1-\alpha} \cdot \lambda \cdot t}} .
$$

The allocation of labor depends on the evolution of the relative price for services, $p$ and the rate of technological change, $\lambda$. Unskilled workers do not benefit from technical progress in either sector. Therefore, the evolution of the relative goods price alone determines the marginal value of unskilled labor in both sectors. If the relative price for services increases, unskilled workers move to the service sector. ${ }^{17}$ Skilled workers move to the sector where their marginal value increases faster. If the relative price of services increases faster than technical progress in manufacturing (at rate $\alpha \cdot \lambda$ ) skilled workers move to services. If $p$ increases at a rate slower than $\alpha \cdot \lambda$ then skilled workers move to manufacturing.

The relative wage of unskilled workers as given by (6) simplifies to

$$
\omega=\frac{w_{u}}{w_{s}}=\left[\frac{p^{\frac{1}{1-\alpha}}+1}{\theta^{\frac{\alpha}{1-\alpha}} \cdot\left(p^{\frac{1}{1-\alpha}}+e^{\frac{\alpha}{1-\alpha} \cdot \lambda \cdot t}\right)}\right]^{1-\alpha}
$$

As discussed in the introduction, the relative goods price is as important as the relative productivity in determining the relative wage. If the goods prices were exogenous (or if goods demand was perfectly elastic and always adjusted to changes in supply) then skillbiased technological change $(\lambda>0)$ would drive the relative wage down to zero. But in this setting, goods prices are endogenous and goods demand is not perfectly elastic. If the relative goods price $p$ increases fast enough (at a rate faster than $\alpha \cdot \lambda$ ), then the relative factor price does not converge to zero, but to $\frac{1}{\theta^{\alpha}}$. Factor price inequality does not increase endlessly in that case, because the price increase in services (from which unskilled workers benefit superproportionally) makes up for the lack of productivity gains.

\footnotetext{
${ }^{17}$ Unless services and manufactured goods are perfect substitutes, the relative price for services must increase in equilibrium because-due to the absence of technical progress in the service sector-the relative production costs of services increase.
} 


\subsection{Long-Run Behavior of the Equilibrium Outcomes}

The evolution of the equilibrium relative price for services is determined by substituting (7) into (5):

$$
p^{\frac{1}{1-\alpha}+\frac{\rho}{1-\rho}}=\frac{\left(p^{\frac{1}{1-\alpha}}+e^{\frac{\alpha}{1-\alpha} \cdot \lambda \cdot t}\right)^{\alpha}+\theta^{\alpha} \cdot e^{\frac{\alpha}{1-\alpha} \lambda \cdot t} \cdot\left(p^{\frac{1}{1-\alpha}}+1\right)^{\alpha}}{\left(p^{\frac{1}{1-\alpha}}+e^{\frac{\alpha}{1-\alpha} \cdot \lambda \cdot t}\right)^{\alpha}+\theta^{\alpha} \cdot\left(p^{\frac{1}{1-\alpha}}+1\right)^{\alpha}}
$$

The evolution of the relative goods price over time as given in (11) is rather complex. But it converges fairly quickly to an exponential growth path where the growth rate depends on the elasticity of substitution in consumption demand.

Proposition 2 The limit of the growth rate of the relative goods price as a function of the substitution elasticity in consumption demand $\sigma$ is given by:

$$
\lim _{t \rightarrow \infty} \frac{\dot{p}}{p}=\left\{\begin{array}{ccc}
\frac{\alpha}{\alpha+(1-\alpha) \cdot \sigma} \cdot \lambda & \Leftrightarrow & 0 \leq \sigma \leq 1 \\
\frac{\alpha}{\sigma} \cdot \lambda & \Leftrightarrow & \sigma \geq 1
\end{array}\right.
$$

\section{Proof. See Appendix A.2.}

If the goods are perfect substitutes $(\sigma=\infty)$ the relative price must be constant and equal to 1 . If the consumption goods are perfect complements $(\sigma=0)$, ie, if consumers always want to consume both goods in a fixed ratio, the relative price of the service good (which does not benefit from technical progress) increases at a rate equal to $\lambda$ (thus faster than productivity in manufacturing which grows at rate $\alpha \cdot \lambda$.) ${ }^{18}$ For intermediate values of the elasticity of substitution between the consumption goods, the relative goods price increases at a rate between 0 and $\lambda$. If the substitutability between the consumption goods is sufficiently low, then demand for services increases as people get richer thanks to technical progress in the manufacturing sector. In general equilibrium, the benefits from technical progress in the manufacturing sector "trickle down" to the service sector through consumption demand. People are willing to pay an ever higher price for services (relative to manufacturing) if they cannot substitute easily between the goods. This has consequences for the relative wage. Plugging (12) into (10) yields the limit of the relative wage as presented in the following proposition:

\footnotetext{
${ }^{18}$ To be exact, one has to distinguish the rate of technical progress $\alpha \cdot \lambda$ from the growth rate of marginal productivity $\left(\frac{\partial \dot{Y}_{m}}{\partial l_{m s}}\right) / \frac{\partial Y_{m}}{\partial l_{m s}}=\alpha \cdot \lambda-(1-\alpha) \cdot \frac{i_{m s}}{l_{m s}}$ which is larger than $\alpha \cdot \lambda$ because employment in manufacturing falls and marginal productivity is decreasing.
} 
Proposition 3 As time goes to infinity, the limit of the relative wage is given by

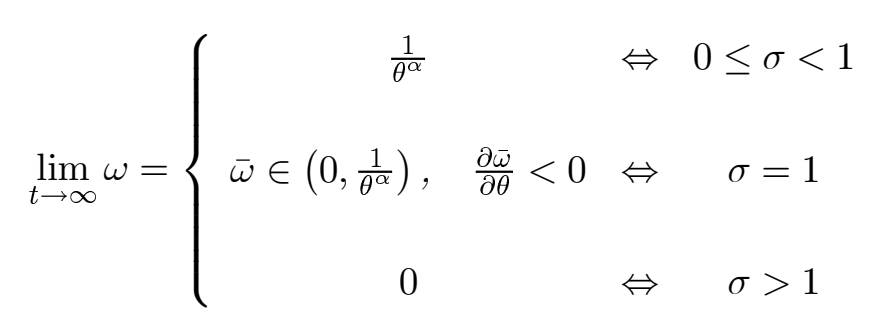

where $\bar{\omega}$ is given by $\theta^{\alpha} \cdot \bar{\omega}=\left(\frac{1-\bar{\omega}}{2}\right)^{1-\alpha}$.

Again, the substitutability between the consumption goods is crucial. If the consumption goods are perfect substitutes $(\sigma=\infty)$, the relative price for services cannot grow. The evolution of wages is determined solely by technical progress from which only skilled workers benefit. The relative wage of unskilled workers falls to zero. Wage inequality grows without bounds. If on the other hand, the consumption goods are perfect complements $(\sigma=0)$, people want to consume these goods in fixed proportions. Their willingness to pay for services grows faster with their incomes. In the long run, unskilled workers - who have a comparative advantage in services - benefit from this price increase. Their relative wage increases - and wage inequality falls - to its initial level. As long as the elasticity of substitution between the two consumption goods is not larger than 1, the relative wage converges to a positive constant and wage inequality does not increase without limits.

The analysis of limits as time goes to infinity may seem somewhat odd in this context because in the long run we are all dead. But note that the limit of the relative wage constitutes a lower bound: Even if technological change continues to be skill-biased forever, in this setting, the relative wage will never fall below $\bar{\omega}$ if the substitution elasticity is not higher than 1 . On the transition path, the relative wage will always be above that value. This is the way one should interpret these limits. The next subsection considers the evolution of wage inequality in the short-run.

\subsection{Short-Run Behavior of the Equilibrium Outcomes}

In the previous subsection, it is shown that under plausible assumptions, wage inequality will not increase beyond limits even if technological change continues to be skill-biased for ever. In this subsection, I consider the short-run evolution of prices and quantities. Figure 1 depicts the evolution over time of the relative wage of unskilled workers as a function of the elasticity of substitution in consumption demand. Wage inequality first increases as the relative wage for unskilled labor falls. But after some time, the relative wage begins to rise again and wage inequality falls. The smaller is the substitution elasticity, the earlier does the relative wage for unskilled labor begin to rise. ${ }^{19}$

\footnotetext{
${ }^{19}$ In the case of Cobb-Douglas-Preferences, the relative wage does not start to increase again but does not fall to 0 either. Wage inequality stabilizes. The general shape of the graph does not depend on the parameter values.
} 


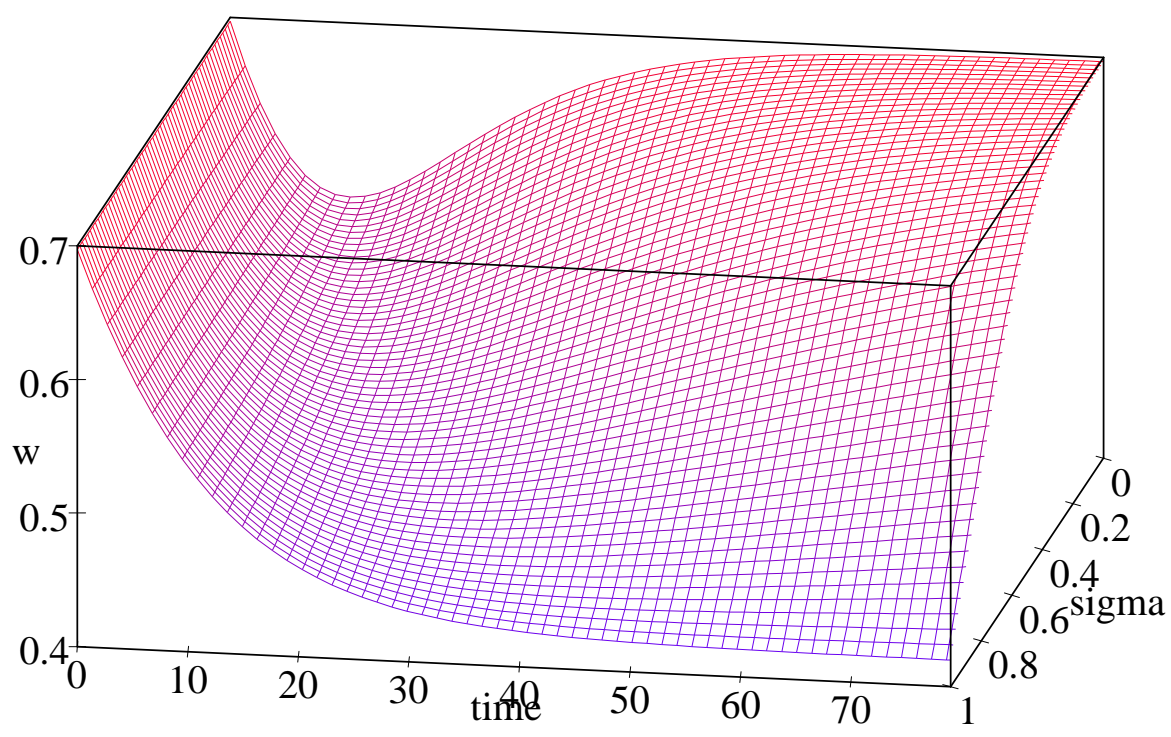

Figure 1:Simulation of the evolution of the relative wage for unskilled labor, $\omega$, (vertical axis) over time as a function of the substitution elasticity in factor demand $\sigma$ for $\theta=2, \lambda=0.1, \alpha=0.5$.

What are the reasons for these non-monotonic dynamics? There are two counteracting forces in the determination of the relative factor price: The evolution of relative productivities (boosting wage inequality) and the evolution of the relative goods price (dampening wage inequality). At first, the effect of widening disparities in productivities dominates: Wage inequality rises. Later on, the effect of the increasing relative price of services dominates. Wage inequality falls again. Why is this?

Starting from an allocation where unskilled and skilled workers are allocated rather evenly across sectors, disparities in the evolution of goods supply (which favors manufacturing) and demand (which prefers equal proportions) can be accommodated by reallocation of labor towards the service sector without substantial changes in goods prices. As time goes on and ever fewer workers remain in manufacturing more substantial changes in prices and wages are needed, to still attract to the service sector.

This pattern of increasing and decreasing wage inequality is consistent with the evolution of the skill-specific wage structure and sectoral employment in the 1980s and 1990s.

\section{Discussion of the Results and Conclusion}

The aim of this paper is to show that skill-biased technological change does not necessarily imply increasing wage inequality. The reason is that wages depend not only on productivity but also on goods prices. In other words: Factor prices depend not only on the technology of firms but also on the preferences of consumers. The role of consumers' preferences has 
so far been neglected in the literature. The results of the paper are corroborated by the evolution of the wage structure in the 1980s and 1990s.

\section{Basic Story}

Technical progress leads to large productivity gains in manufacturing but much less so in services. As services and manufactured goods are complements in consumption, rising incomes (brought about by productivity gains in manufacturing) lead to increasing demand for manufactured goods and services. Because productivity rises faster in manufacturing, an increase in production in both sectors requires that labor shifts to services. As the production of services is intensive in the use of unskilled labor, the relative demand for unskilled labor rises and wage inequality declines. The magnitude of this effect depends on the elasticity of substitution between services and manufactured goods. By services, I mean especially services that do not require specific skills and do not benefit greatly from technological innovations. In particular, some basic unskilled services seem to match these requirements. Think of house cleaning, lawn mowing, shoe-shining, car washing, ironing, walking dogs, pizza and drinks delivery, etc. These services do not require special skills and they do not greatly benefit from technical progress. In addition, these services are certainly complements rather than substitutes to other goods. The idea is that buying these goods is equivalent to buying leisure time. And with increasing wages, leisure time becomes more valuable so that people are willing to pay a higher price for services that allow them to enjoy more leisure time. ${ }^{20}$ The size of this sector of basic services might seem too small to have any significant effect. On the other hand, the potential size of this sector is probably by far larger than it first appears. And - in addition to these services to private households - there is an even much larger demand for services to firms that do not require special skills either. Think of office-cleaning, window cleaning, car-park attendants, bicycle messengers, call centers, factory canteen staff, etc. And finally, remember from Section 2 that: "...the number of hairdressers grew more than 300 per cent between 1992 and 1999. That was more than three times the growth of consultants ..."21

\section{Skill-Biased Technological Change and Decreasing Wage Inequality in the 1990s}

There is a growing literature on the narrowing of the educational wage structure in the 1990s. The empirical evidence seems uncontroversial. Theoretical explanations for this evolution are as yet inconclusive and discontenting. Some argue in the tradition of Douglas (1926) and Tinbergen (1975) who view the evolution of the wage structure (at least

\footnotetext{
${ }^{20}$ If people care for leisure, optimal allocation of time (between leisure and labor) requires that on the margin, the willingness to pay for an additional unit of leisure be equal to the wage earned for the same unit of labor.

${ }^{21}$ It can be expected that in the future, increasing female labor markt participation and an increasing share of older people will further boost the demand for household services.
} 
partially) as depending on a race between technological development and educational advance. But this view is inconsistent with the fact that during the 1990s, the growth in the relative supply of skilled workers slowed down. Others call into question the role of skill-biased technological change for the evolution of the wage structure altogether. In that case, the evolution of the skill-premium in the 1980s remains in need of an explanation.

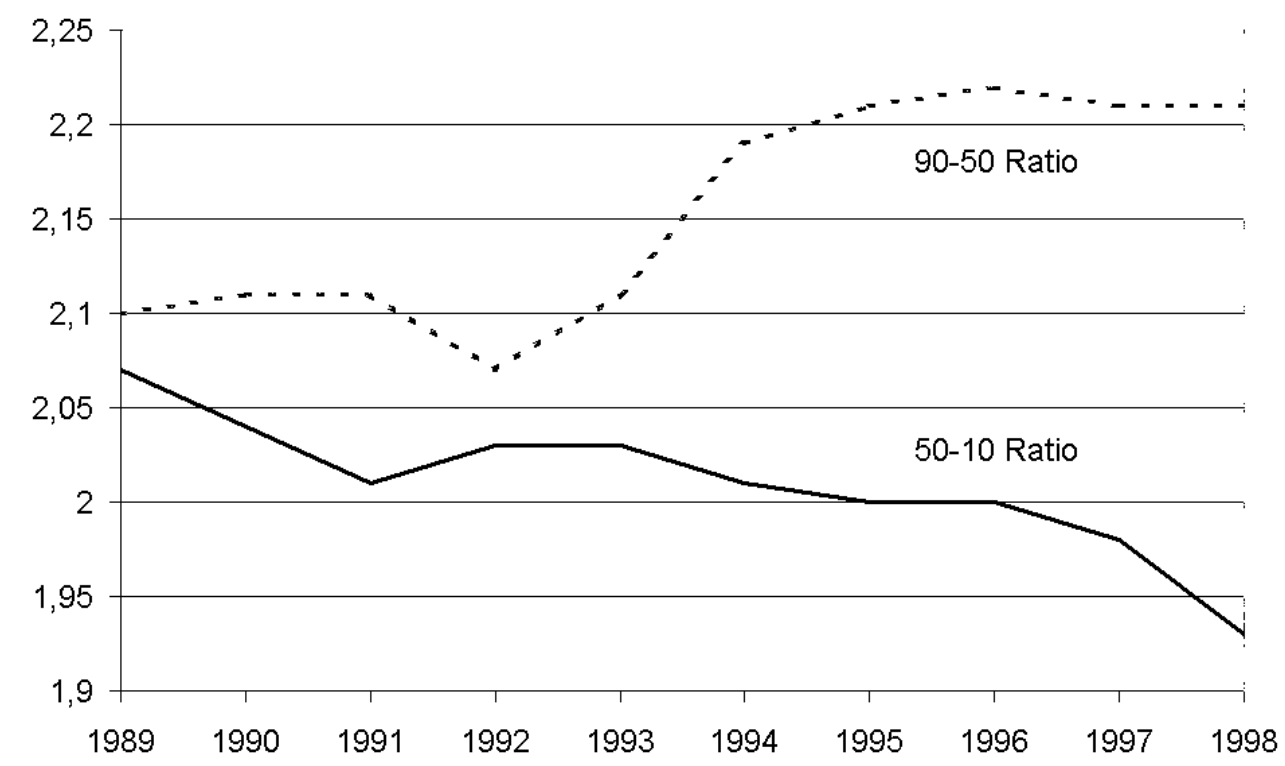

Figure 3: Ratios of the $90^{\text {th }}$ to $50^{\text {th }}$ percentile and the $50^{\text {th }}$ to $10^{\text {th }}$ percentile of the U.S. wage distribution. Source: Bernstein and Mishel (1999), Current Population Survey.

In this paper, I argue that skill-biased technological change can explain both, the widening of the wage structure in the 1980s and the subsequent narrowing in the 1990s.

\section{Wage Inequality in the 1990s Rose at the Top and Fell at the Bottom}

A number of authors have studied the evolution of the wage structure in the 1990s in more detail. ${ }^{22}$ They found that while the gap between the 90th percentile and the 10th percentile remained fairly stable over the 1990s, the gap between the 90th percentile and the 50th percentile widened further whereas the gap between the 50th and the 10th percentile narrowed (see Figure 3). Also, the premium for graduate degrees vs. 4 years of college has increased further in the 1990s while the premium for 4 years of college vs. a high school degree has leveled off. Bernstein and Mishel conclude that the puzzling evidence of the 1990s invalidates the "skill-biased technological change hypothesis" as an explanation for the increasing wage inequality in the 1980s:

"The failure of the new economy to generate a surge in the relative demand for

\footnotetext{
${ }^{22}$ See, eg, Bernstein and Mishel (1999), Katz (2000), Murphy and Welch 2001, Mishel and Bernstein 2001, and Prasad (2002).
} 
skill casts doubt on the interpretation of the earlier growth of wage inequality as being technology-driven."

Another interpretation of the coincidence of growing wage dispersion at the top and falling wage dispersion at the bottom of the wage distribution is consistent with the model presented in this paper: Workers with medium and high skills work in the same sectors (which benefit from technical progress). So, changes in relative prices induced by technological change affect them symmetrically. In other words, workers with medium skills do not benefit much from skill-biased technological change and they do not benefit from rising prices for the unskill-intensive goods either.

\section{The Difference between Hairdressers and (other) Unskilled Workers}

In Section 2, the example of hairdressing is given as an illustration of how unskilled workers can benefit from skill-biased technological change through relative price changes. Yet, unlike the hairdressers, the (other) unskilled workers saw their relative wages drop for roughly a decade before they began to rise again in the mid 1990s. What is different between hairdressers and other unskilled workers? The difference is that hairdressers do not compete with skilled workers within the same sector (where relative productivities alone determine relative wages) but only across sectors (where the relative goods price becomes important). ${ }^{23}$ (Other) unskilled workers compete with skilled workers across and within sectors. So, unskilled workers are facing two counteracting forces: Skill-biased technological change harms their relative position within sectors and changes in relative goods prices - induced by a sector-bias against unskill-intensive goods - improve their relative position across sectors. Over time, the direct technology effect (boosting wage inequality) dominates first while the indirect price effect (dampening wage inequality) dominates in the long run.

\footnotetext{
${ }^{23}$ The example of hairdressing can be captured within the framework of the model presented in Section 3. Let factor 1 be hairdressers and factor 2 be all other workers. Sector 1 is the hairdressing trade and sector 2 consists of all other sectors in the economy. The fact that hairdressers work only in the hairdressing sector while the other workers work only in the other sectors implies $\theta_{12}=\theta_{21}=0$ and $\theta_{11}=\theta_{22}=\theta$. The absence of technical progress in the hairdressing sector implies $\lambda_{11}=0$. In this case equation (5) and (6) simplify to

$$
\frac{p_{\text {haircuts }}}{p_{\text {other goods }}}=e^{\frac{\alpha \cdot \lambda_{22}}{\sigma} \cdot t} \quad \frac{w_{\text {hairdressers }}}{w_{\text {others }}}=e^{-\alpha \cdot \frac{\sigma-1}{\sigma} \cdot \lambda_{22} \cdot t}
$$

The price for haircuts increases over time (unless they are perfect substitutes to the other goods). The relative wage of hairdressers increases over time if the elasticity of substitution between haircuts and the other goods is smaller than 1 .
} 


\section{A Appendix}

\section{A.1 Proof of Proposition 1: Existence and Uniqueness of the General Equilibrium}

\section{Existence of the Equilibrium Given by (5) in Proposition 1}

Equation (5) can be rearranged to get

$$
\frac{1}{p^{\frac{1}{1-\rho}}}=p^{\frac{\alpha}{1-\alpha}} \cdot \frac{\sum_{j=1}^{2}\left(\frac{\left[\frac{\theta_{1 j}}{\theta_{2 j}^{\alpha}} \cdot e^{\left(\lambda_{1 j}-\alpha \cdot \lambda_{2 j}\right) \cdot t}\right]^{\frac{1}{1-\alpha}}}{p^{\frac{1}{1-\alpha}} \cdot\left[\frac{\theta_{1 j}}{\theta_{2 j}} \cdot e^{\left(\lambda_{1 j}-\lambda_{2 j}\right) \cdot t}\right]^{\frac{\alpha}{1-\alpha}}+1}\right)^{\alpha}}{\sum_{j=1}^{2}\left(\frac{\theta_{2 j} \cdot e^{\lambda_{2 j} \cdot t}}{p^{\frac{1}{1-\alpha}} \cdot\left[\frac{\theta_{1 j}}{\theta_{2 j}} \cdot e^{\left(\lambda_{1 j}-\lambda_{2 j}\right) \cdot t}\right]^{\frac{\alpha}{1-\alpha}}+1}\right)^{\alpha}}
$$

The left hand side of the equation $(L H S)$ is relative demand for good 1 and the right hand side $(R H S)$ is relative supply of good 1 , both as functions of the relative goods price. At $p=0$, relative demand for good 1 is infinite and relative supply is $0: \operatorname{LHS}(0)=\infty>$ $R H S(0)=0$. The limit of relative demand for $p \rightarrow \infty$ is 0 while the limit of relative supply for $p \rightarrow \infty$ is infinite: $\lim _{p \rightarrow \infty} L H S(p)=0<\lim _{p \rightarrow \infty} R H S(p)=\infty$. Both sides of the equation are continuous in $p$. Therefore, at least one $p$ must exist that makes both sides equal. This establishes the existence of the general equilibrium.

\section{Uniqueness of the Equilibrium Given by (5) in Proposition 1}

The left hand side of (5) is monotonously decreasing in $p$ while the right hand side is monotonously increasing in $p$. Thus, if an equilibrium exists, it must be unique.

\section{A.2 Proof of Proposition 2}

Taking limits of equation (11) as time goes to infinity yields:

$$
\begin{aligned}
& \lim _{t \rightarrow \infty} \frac{p}{e^{\frac{\alpha}{(1-\alpha) \cdot \sigma+\alpha} \cdot \lambda \cdot t}}=\left(\frac{\theta^{\alpha}}{1+\theta^{\alpha}}\right)^{\frac{1-\alpha}{(1-\alpha) \cdot \sigma+\alpha}} \Leftrightarrow 0 \leq \sigma<1 \\
& \lim _{t \rightarrow \infty} \frac{p}{e^{\alpha \cdot \lambda \cdot t}} \quad=\quad \bar{p} \in\left[\frac{1}{2}, 1\right] \quad \Leftrightarrow \quad \sigma=1 \\
& \lim _{t \rightarrow \infty} \frac{p}{e^{\frac{\alpha}{\sigma} \cdot \lambda \cdot t}} \quad=\quad \theta^{\frac{\alpha}{\sigma}} \quad \Leftrightarrow \quad \sigma>1
\end{aligned}
$$

where $\bar{p}$ is a constant, implicitly given by $\bar{p} \cdot\left(\bar{p}^{\frac{1}{1-\alpha}}+1\right)^{\alpha}=\theta^{\alpha} \cdot\left(1-\bar{p}^{\frac{1}{1-\alpha}}\right)$. This can easily be checked by substituting these values into equation (11) and taking limits as time goes to infinity. From Proposition 1 follows that these limits are the unique solutions to (11) as time goes to infinity. 


\section{References}

Acemoglu, D. (2002): "Technical Change, Inequality, and the Labor Market," Journal of Economic Literature, 40, 7-72.

Aghion, P., E. Caroli, and C. García-Peñalosa (1999): "Inequality and Economic Growth: The Perspectives of the New Growth Theories," Journal of Economic Literature, 37(4), 1615-1661.

Autor, D. H., L. F. Katz, and A. B. Krueger (1998): "Computing Inequality: Have Computers Changed the Labor Market?," Quarterly Journal of Economics, 113(4), 1169 $-1213$.

Bernstein, J., And L. Mishel (1999): "Wages Gain Ground," EPI Issue Brief, 129.

Card, D., and J. E. DiNardo (2002): "Skill Biased Technological Change and Rising Wage Inequality: Some Problems and Puzzles," Journal of Labor Economics, 20(4), $733-783$.

Daly, M., and R. Valletta (2003): "Earnings Inequality and Earnings Mobility in the U.S.," FRBSF Economic Letter, 2003-28, 1-3.

Dickens, R., And D. T. Ellwood (2001): "Whither Poverty in Great Britain and the United States? The Determinants of Changing Poverty and Whether Work Will Work," Centre for Economic Performance DP, No. 506, London School of Economics.

Douglas, P. (1926): "What is Happening to the White-Collar-Job-Market?," System: The Magazine of Business.

Gottschalk, P., and T. M. Smeeding (1997): "Cross National Comparison of Earnings and Income Inequality," Journal of Economic Literature, 35(2), 633-678.

Gregg, P., And A. Manning (1997): "Skill-Biassed Change, Unemployment and Wage Inequality," European Economic Review, 41(6), 1173 - 1200.

Haskel, J. E. (2000): "Trade and Labor Approaches to Wage Inequality," Review of International Economics, 8(3).

Haskel, J. E., and M. J. Slaughter (2002): "Does the Sector Bias of Skill-Biased Technical Change Explain Changing Skill Premia?," European Economic Review, 46(10), $1757-1783$.

KAtz, L. F. (2000): "Technological Change, Computerization, and the Wage Structure," in Understanding the Digital Economy: Data, Tools, and Research, ed. by E. Brynjolfsson, and B. Kahin, pp. 217-244, Cambridge, MA. MIT Press.

Kongsamut, P., S. Rebelo, and D. Xie (2001): "Beyond Balanced Growth," Review of Economic Studies, 68(4), 869 - 882. 
Leamer, E. (1996): "Wage Inequality from International Competition and Technological Change: Theory and Country Experience," American Economic Review, 86(2), 309 314.

(1997): "In Search of Stolper-Samuelson Effects on U.S. Wages," in Exports, Imports and U.S. Wages, ed. by S. Collins, vol. 5427, Washington, DC. Brookings Institution.

Levy, F., And R. J. Murnane (1992): "U.S. Earnings Levels and Earnings Inequality: A Review of Recent Trends and Proposed Explanations," Journal of Economic Literature, 30, 1333-1381.

Machin, S. (2002): "Labour Market Inequality and Changes in the Relative Demand for Skills," Paper for the Royal Statistical Society 'Explanations of Rising Economic Inequality', http://158.143.98.51/ machin/pdf/jrss april 2002.pdf.

Mishel, L., And J. Bernstein (2001): "Wage Inequality and the New Economy in the U.S.: Does IT-Led Growth Lead to Wage Inequality?," Paper presented at IRPP-CSLS Conference, Ottawa, Canada, Economic Policy Institute, Washington.

Murphy, K., And F. Welch (2001): "Wage Differentials in the 1990s: Is the Glass Half-Full or Half-Empty?," in The Causes and Consequences of Increasing Inequality, ed. by F. R. Welch, pp. 341 - 364. University of Chicago Press.

Nahuis, R., and H. L. F. de Groot (2003): "Rising Skill Premia: You Ain't Seen Nothing Yet?," CPB Discussion Paper, Nr. 20. CPB Netherlands Bureau for Economic Policy Analysis, The Hague, The Netherlands.

Nickell, S. (2004): "Poverty and Worklessness in Britain," The Economic Journal, Forthcoming.

Prasad, E. S. (2002): "Wage Inequality in the United Kingdom, 1975-1999," IZA DP, No. 510, Institute for the Study of Labour (IZA), Bonn.

Slaughter, M. J., And J. E. Haskel (1999): "Technological Change as a Driving Force of Rising Income Inequality," in Globalization and Labor, ed. by H. Siebert, pp. 157-180. JCB Mohr, Tübingen.

Tinbergen, J. (1975): Income Differences: Recent Research. North Holland, Amsterdam. 


\section{Discussion Paper Series}

Mannheim Research Institute for the Economics of Aging Universität Mannheim

To order copies, please direct your request to the author of the title in question.

\begin{tabular}{|c|c|c|c|}
\hline Nr. & Autoren & Titel & Jahr \\
\hline $32-03$ & $\begin{array}{l}\text { Axel Börsch-Supan, } \\
\text { Hendrik Jürges, } \\
\text { OliverLipps }\end{array}$ & $\begin{array}{l}\text { SHARE: Building a Panel on Health, Aging and } \\
\text { Retirement in Europe }\end{array}$ & 03 \\
\hline $33-03$ & Florian Heiss & $\begin{array}{l}\text { Wie groß soll die Schwankungsreserve der } \\
\text { gesetzlichen Rentenversicherung sein? }\end{array}$ & 03 \\
\hline $34-03$ & $\begin{array}{l}\text { Axel Börsch-Supan, } \\
\text { Christina B. Wilke }\end{array}$ & $\begin{array}{l}\text { The German Public Pension System: } \\
\text { How it Was, How it Will Be }\end{array}$ & 03 \\
\hline $35-03$ & $\begin{array}{l}\text { Lothar Essig, } \\
\text { Anette Reil-Held }\end{array}$ & Chancen und Risiken der „Riester-Rente“ & 03 \\
\hline $36-03$ & $\begin{array}{l}\text { Barbara Berkel } \\
\text { Axel Börsch-Supan }\end{array}$ & $\begin{array}{l}\text { Pension Reform in Germany: } \\
\text { The Impact on Retirement Decisions }\end{array}$ & 03 \\
\hline $37-03$ & $\begin{array}{l}\text { Axel Börsch-Supan, } \\
\text { Anette Reil-Held and } \\
\text { Christina Benita } \\
\text { Wilke }\end{array}$ & $\begin{array}{l}\text { How to make a Defined Benefit System } \\
\text { Sustainable: } \\
\text { The "Sustainability Factor" in the German Benefit } \\
\text { Indexation Formula }\end{array}$ & 03 \\
\hline $38-03$ & Melanie Lührmann & $\begin{array}{l}\text { Demographic Change, Foresight and International } \\
\text { Capital Flows }\end{array}$ & 03 \\
\hline $39-03$ & $\begin{array}{l}\text { Joachim Winter and } \\
\text { Lothar Essig }\end{array}$ & $\begin{array}{l}\text { Item nonresponse to financial questions in } \\
\text { household surveys: An experimental study of } \\
\text { interviewer and mode effects }\end{array}$ & 03 \\
\hline $40-03$ & Christoph Buchheim & $\begin{array}{l}\text { Das Zusammenspiel von Wirtschaft, Bevölkerung } \\
\text { und Wohlstand aus historischer Sicht }\end{array}$ & 03 \\
\hline $41-03$ & Oliver Lipps & $\begin{array}{l}\text { Stochastische Bevölkerungsprognose für West- } \\
\text { und Ostdeutschland }\end{array}$ & 03 \\
\hline $42-03$ & Axel Börsch-Supan & $\begin{array}{l}\text { What are NDC Pension Systems? What Do They } \\
\text { Bring to Reform Satrategies? }\end{array}$ & 03 \\
\hline $43-04$ & Matthias Weiss & $\begin{array}{l}\text { Employment of Skill Biased Technological } \\
\text { Change when Benefits are Linked to Per-Capita } \\
\text { Income }\end{array}$ & 04 \\
\hline $44-04$ & $\begin{array}{l}\text { Alexander Ludwig } \\
\text { and Torsten Sløk }\end{array}$ & $\begin{array}{l}\text { The relationship between stock prices, house } \\
\text { prices and consumption in OECD countries }\end{array}$ & 04 \\
\hline $45-04$ & Matthias Weiss & $\begin{array}{l}\text { Skill-Biased Technological Change: Is there Hope } \\
\text { for the Unskilled? }\end{array}$ & 04 \\
\hline
\end{tabular}




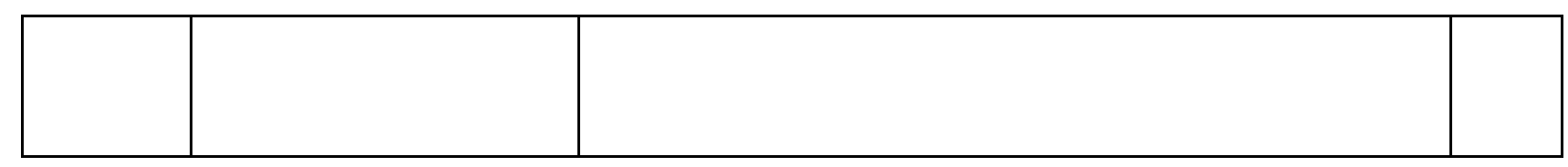

